http://jmscr.igmpublication.org/home/ ISSN (e)-2347-176x ISSN (p) 2455-0450 crossref DOI: https://dx.doi.org/10.18535/jmscr/v8i2.94

\title{
Successful Pregnancy Outcome after Laprotomy (A Case of Pregnancy with Ovarian Tumour)
}

\author{
Authors \\ Dr Shilpi Chowdhury ${ }^{1}$, Dr Soma Bandyopadhyay ${ }^{2}$, Dr Prachi ${ }^{3}$, Dr Bhagyashree ${ }^{4}$ \\ ${ }^{1}$ PGT $2{ }^{\text {nd }}$ year, Dept. of Obstetrics and Gynaecology, KMCH \\ ${ }^{2}$ Professor, Dept. of Obstetrics and Gynaecology, $\mathrm{KMCH}$ \\ ${ }^{3} \mathrm{PGT} 3^{\text {rd }}$ year, Dept. of Obstetrics and Gynaecology, KMCH \\ ${ }^{4} \mathrm{PGT} 2{ }^{\text {nd }}$ year, Dept. of Obstetrics and Gynaecology, KMCH
}

\section{Introduction}

Most common ovarian masses encountered during pregnancy are functional ovarian cysts including follicular and corpus luteal cysts. The other ovarian masses in order are benign cystic teratomas, serous cyst adenomas, mucinous cyst adenomas and endometriomas.

Torsion of ovarian tumour is commonest complication during pregnancy. The diagnosis is establised by the characteristic history, presenting complaints of patient, examination findings and it is confirmed by transvaginal ultrasonography. Whenever, this condition is encountered, it is important to go for immediate surgery.

\section{Aim}

To present a case of successful pregnancy outcome after laprotomy

Setting- Department of Obstetrics and Gynaecology, Katihar Medical College, Katihar

\section{Case Summary}

A 26 year old Primigravida with 2 months amenorrhea presented in obstetric casualty with chief complaint of acute pain abdomen since morning. Pain was all over abdomen with no aggravating or relieving factors. There was no history of nausea, vomiting, fever, syncopal attack, bladder or bowel complaints. There was no history of discharge or bleeding per vaginum. Her previous menstrual cycle was normal. There was no significant past, personal or any surgical history.

\section{On examination}

BP- 100/70 $\mathrm{mmHg}$

PR- 120/min

Afebrile, temp $98.6 \mathrm{~F}$

Pallor +

No icterus, cyanosis, clubbing, lymphadenopathy, edema

Per abdomen: Uterus height corresponds to 1618 weeks size of gestation, tenderness ++ Immediately preliminary investigations and ultrasonography done.

\section{Investigation}

Hb-9.6 gm\%

ABORh- O positive

HIV- Non reactive

HBsAg- Non reactive

AntiHCV - Non reactive 
Platelet count- $3.3 \mathrm{~L} / \mathrm{cmm}$

RBS - $118 \mathrm{mg} / \mathrm{dl}$

Sr. Urea- $28 \mathrm{mg} / \mathrm{dl}$

Sr. Creatinine- $0.8 \mathrm{mg} / \mathrm{dl}$

Sr. Bili- $0.7 \mathrm{mg} / \mathrm{dl}$

SGOT- 36 IU/L

SGPT- 42 IU/L

ALP- 140 IU/L

TLC- $14000 \mathrm{cu} / \mathrm{mm}$

ESR- $20 \mathrm{~mm} / \mathrm{hr}$

USG- A single live fetus of 8 weeks gestation along with left side large ovarian tumour measuring 10x11 cms

\section{Operative Procedure}

After all preliminary investigations, patient was taken up for emergency laprotomy in view of suspected torsion of ovarian tumour.

Per- operative gross morphology was pedunculated left sided large ovarian tumour of size approx (10X $12 \mathrm{cms})$ with torsion, twisted twice around the ovarian pedicle with compromised vascular supply of nearby tissue. The left fallopian tube was twisted at the cornua and stretched over the tumour.

The pedicle of ovarian tumour was untwisted and left salphingo-oopherectomy was done.

Other side ovary and fallopian tube were found normal. Hemostasis secured and abdomen was closed in layers. Specimen sent for histopathological examination.

\section{Post Operative Period}

She was given injectable antibiotics with uterine relaxants.

Post operative period was uneventful and patient was discharged on $8^{\text {th }}$ postoperative day and to be followed on OPD basis. Histopathology report came out to be MUCINOUS CYSTADENOMA.

\section{Post Discharge Antenatal Care}

Patient was under regular antenatal check up with supplements of Iron, Calcium and support of Micronised Progesterone. At the end of 37 completed weeks of gestation, She delivered a term single live female baby of weight $2.4 \mathrm{~kg}$ by LSCS.

\section{Discussion}

Ovarian tumour can cause severe, acute or intermittent symptoms caused by torsion, intraperitoneal rupture or bleeding in ovarian tissue. These conditions can represent a true surgical emergency or urgency and their diagnosis can be challenging.

Frequency of ovarian tumours being coexistent with pregnancy is $1: 1000$ and among these frequencies of being malignant is approx 1:15000 to $1: 32000$ pregnancies. Torsion is most common and serious complication of benign ovarian cysts during pregnancy.

Ovarian torsion therefore occur most commonly during $1^{\text {st }}$ trimester, less commonly during $2^{\text {nd }}$ trimester and rarely during $3^{\text {rd }}$ trimester.

The mucinous cyst adenomas are one of the benign epithelial ovarian tumours, which tend to be unilocular and multilocular with smooth surface and contains mucinous fluid.

They comprise of $12-15 \%$ of all ovarian tumours. Around $75 \%$ of all are benign, while $10 \%$ are borderline and $15 \%$ are invasive carcinomas.

\section{Conclusion}

After thorough review of history, examination and investigation exploratory laparotomy with left sided salphingo-oopherectomy was done for large ovarian tumour $(10 \times 11 \mathrm{~cm})$ approx with torsion. With proper post operative care and antenatal check-ups she delivered a full term healthy female baby at 37 completed weeks of gestation.

So, timely intervention can significantly decrease, morbidity and mortality of both mother and baby.

\section{Bibliography}

1. Cunningham, F.G., Lebeno, K. J., et al, editors. Williams obstetrics chapter 63( $25^{\text {th }} \quad$ ed.) Newyork McGraw-Hill Education; 2018 : Pg.1197-1199.

2. Berek, J.S., \& Novak, E.(2012). Berek and Novak's gynaecology. Chapter 37. $\left(15^{\text {th }}\right.$ ed). Philadelphia; Lppincott Williams \& wilkkins. 
3. Whitecar MP, Turners, Higby MK. Adnexal masses during pregnancy, a review of 130 cases undergoing surgical management. Am J Obstet Gynecol 1999; 181: 19-24.

4. Hooverx, Jenkins TR (2011), Evaluation \& Management of adenexal mass in pregnancy. ACOG (205; 97-102). 